\title{
Agglutination of human and animal erythrocytes in marine unicellular algae
}

\author{
W-R Liao and R Huang \\ Institute of Oceanography, National Taiwan University, Taipei 100, Taiwan
}

\begin{abstract}
Ethanol extracts of $\mathbf{1 2}$ marine unicellular algae were assayed for agglutinating activity against native and enzymetreated human and animal erythrocytes. All of the algae assayed agglutinated at least one group of normal erythrocytes from humans. Notably, all algal extracts agglutinated erythrocytes of hemophilia patients arising from coagulation disorders. Meanwhile, all algae had a strong reaction with monkey erythrocytes, but to a lesser extent or not at all with sheep erythrocytes. Both trypsin and pronase improved the detection of most algal agglutinins and caused a drastic increase in hemagglutinating activity after treatment for $\mathbf{2 h}$ or more. However, hemagglutinating activity decreased or disappeared completely when two extracts of different algal species were combined. Journal of Industrial Microbiology \& Biotechnology (2000) 24, 262-266.
\end{abstract}

Keywords: agglutinating activity; marine unicellular algae; erythrocytes; enzymes

\section{Introduction}

Marine algae contain lectins or agglutinins, which are proteinaceous compounds and have specific binding characteristics with carbohydrates to produce unique biological activities $[3,8]$. Lectins can cause coagulation in human and animal erythrocytes, bacteria, yeast, blue-green algae and even mouse tumor cells $[4,9,11,16]$. They also stimulate mitogensis of human lymphocytes [12,15]. Although many marine algae have been assayed for agglutination of human and animal erythrocytes, those investigations were limited to macroalgae, ie seaweeds, in a few ecological areas $[1,2,9,11,17]$. Agglutinating activity varies greatly between algal species and the sources of erythrocytes $[1,2,9]$. Such activity can be induced markedly by modifying the extraction process, ie using enzyme treatments and additives $[2,12-14,16]$. To date, research on agglutination with human hemophiliac blood or other coagulation disorders by marine algae has not been reported. A few species of seaweeds have been purified with the biochemical characteristics of the lectins specified $[5,11,17,18]$. Rogers and Fish [17] reviewed the biochemical characteristics of lectins in various seaweeds and their hemagglutination with human erythrocytes. Yet lectins and their biochemical characteristics in unicellular algae remain unknown. Recently, we found agglutination of human and animal erythrocytes by the extracts of chrysophycean algae (Liao et al, unpublished data), revealing that lectins also exist in single-cell algae. Therefore, we examined more unicellular algae for hemagglutination for a better understanding of the biochemical characteristics of lectins. Additionally, we combined the extracts from different species and assayed their hemagglutination after combination.

Correspondence: R Huang, Institute of Oceanography, National Taiwan University, Taipei 100, Taiwan. E-mail: rang@ccms.ntu.edu.tw Received 24 September 1999; accepted 6 January 2000

\section{Materials and methods}

Algal cultures

Twelve species of marine unicellular algae belonging to Cyanophyceae, Chlorophyceae, Bacillariophyceae, Dinophyceae, Prymnesiophyceae, Eustigmatophyceae and Rhodophyceae were used for the hemagglutination assays. Algal cells were grown xenically in unialgal cultures in an $\mathrm{f} / 2$ enriched seawater medium [10] at $25^{\circ} \mathrm{C}$ and $15-17 \mathrm{~W}$ $\mathrm{m}^{-2}$ irradiance of $\mathrm{L}: \mathrm{D}=12: 12$ before assaying. The algal cells used in the assay were in exponential phase (3-5 days after inoculation in the enriched medium).

\section{Preparation of algal materials}

Cultures (2-3-litre) of algae were filtered through Whatman glass filters $(\mathrm{GF} / \mathrm{C})$ at low-pressure vacuum, ie 1/2 atm, 23 drops of Milli Q water (previously distilled) were added to the filter to wash out any salt remaining on the cells and filter. Cells on the filter membrane were then freeze-dried at $-20^{\circ} \mathrm{C}$ for $48 \mathrm{~h}$. Dried cells on the filter were scraped down as pellets and weighed. Algal pellets of approximately $0.2 \mathrm{~g}$ immersed in liquid nitrogen were ground into powder and then kept at $-20^{\circ} \mathrm{C}$ until used.

\section{Algal extraction}

The extraction procedure followed that of Kawakubo et al [14]. Ethanol (20\%) was added to the algal powder (1:10, w:v), and the mixture was stirred overnight at $4^{\circ} \mathrm{C}$. After centrifugation, the supernatant mixture was collected for use in the agglutination assay.

\section{Preparation of erythrocytes}

The agglutinating activity of algal extracts was assayed using fresh human and animal erythrocytes. Some of the human erythrocytes were normal $\mathrm{A}, \mathrm{B}, \mathrm{O}$ and $\mathrm{AB}$ groups, and others were coagulation disorder (hemophilia) assigned to failure in activating thrombin within the prothrombin time (PT) or the activated partial thromboplastin time (APTT). The disorders arise from the lack of factors VII, 
VIII and IX in the blood of patients. Human blood was obtained from the Union Clinical Laboratory, Taipei, while monkey and sheep erythrocytes were purchased from Accurate Chemical \& Scientific Corporation, New York. All of the erythrocytes were concentrated by centrifugation in a $50 \mathrm{mM}$ phosphate buffer $(\mathrm{pH} 7.2)$ containing $0.1 \mathrm{M}$ sodium chloride [13]. This phosphate-buffered saline (PBS) was used to dilute the concentrated erythrocytes to $2 \%$ of their original volume. The erythrocytes were then used directly (native) in the assay for agglutination or treated with $2 \%$ trypsin or $0.5 \%$ pronase in $\mathrm{PBS}$ at $37^{\circ} \mathrm{C}$ for $2 \mathrm{~h}$ (enzyme-treated) before using them in assays.

\section{Hemagglutinating activity assay}

Aliquots of algal extracts from serial two-fold dilutions were added separately to 96-well micro-V-plates. An equal volume of erythrocyte suspension was added to each well, mixed with extracts at room temperature and allowed to stand for $2 \mathrm{~h}$. Hemagglutination was examined and its activity, which was a reciprocal of the highest two-fold dilution exhibiting positive agglutination, was recorded. The control was the aqueous ethanol without algal extracts. For each species, the assay was carried out in duplicate samples. Activity was determined with an error of $\pm 2^{1}$ titers.

\section{Agglutinating activity of the combined extracts}

Equal volumes of algal extracts from two algal species were mixed together and shaken. The mixture was placed in wells for the assay of hemagglutination as described above.

\section{Inhibition test with sugars}

Sugar $(50 \mu \mathrm{l}$ of $0.5 \mathrm{M})$ in PBS was mixed thoroughly with an equal volume of algal extract and kept at room temperature for $30 \mathrm{~min}$. The extracts were assayed again against native erythrocytes of the human $\mathrm{O}$ group to make sure of their agglutinating activity prior to mixing. Then $50 \mu \mathrm{l}$ of the mixture was added to a well of a micro-V-plate, mixed with an equal volume of $2 \%$ type $\mathrm{O}$ erythrocytes. Agglutination of erythrocytes was examined after $2 \mathrm{~h}$. Sugars used in the test were the monosaccharides, D-glucose, $\mathrm{D}(+)$-galacotse, $\mathrm{D}(+)$-mannose, methy- $\alpha$-D-glucoside, methyl- $\alpha$-Dmannoside and the oligosaccharides, sucrose, lactose and raffinose.

\section{Results}

\section{Agglutination of human erythrocytes}

Agglutination of human erythrocytes by marine algae varies greatly among algal species and erythrocytes assayed. All of the algae assayed agglutinated at least one group of normal erythrocytes, with maximum activity reaching $2^{4-25}$ titers (Table 1). Meanwhile, almost all species agglutinated strongly native $\mathrm{O}$ and $\mathrm{AB}$ erythrocytes, but to a lesser extent for A erythrocytes. The blue-green alga Synechococcus sp and the green alga Ankistrodesmus sp displayed extremely strong affinity for $\mathrm{O}$ erythrocytes, ie $2^{24}-2^{25}$ titers, followed by Hymenomonas sp and Pavlova salina, reaching $2^{12-13}$ titers. Four species were non-specific for human blood cells.
Table 1 Hemagglutinating activities of marine unicellular algae against native and trypsin-treated human erythrocytes; the activity is expressed as titer

\begin{tabular}{|c|c|c|c|c|c|c|c|c|}
\hline \multirow[t]{2}{*}{ Algal species } & \multicolumn{4}{|c|}{ Native } & \multicolumn{4}{|c|}{ Trypsin } \\
\hline & A & B & $\mathrm{O}$ & $\mathrm{AB}$ & A & B & $\mathrm{O}$ & $\mathrm{AB}$ \\
\hline $\begin{array}{l}\text { Cynophyceae } \\
\text { Synechococcus sp }\end{array}$ & 0 & $2^{2}$ & $2^{24}$ & $2^{2}$ & $2^{1}$ & $2^{3}$ & $2^{24}$ & $2^{7}$ \\
\hline $\begin{array}{l}\text { Chlorophyceae } \\
\text { Ankistrodesmus sp } \\
\text { Chlorella ellipoidea }\end{array}$ & $\begin{array}{l}0 \\
0\end{array}$ & $\begin{array}{l}0 \\
0\end{array}$ & $\begin{array}{l}2^{25} \\
2^{3}\end{array}$ & $\begin{array}{l}0 \\
2^{5}\end{array}$ & $\begin{array}{l}2^{1} \\
2^{2}\end{array}$ & $\begin{array}{l}2^{2} \\
2^{1}\end{array}$ & $\begin{array}{l}2^{12} \\
2^{5}\end{array}$ & $\begin{array}{l}2^{1} \\
2^{6}\end{array}$ \\
\hline $\begin{array}{l}\text { Dinophyceae } \\
\text { Gyrodinium instriatum } \\
\text { Prorocentrum minimum }\end{array}$ & $\begin{array}{l}2^{4} \\
2^{3}\end{array}$ & $\begin{array}{l}2^{1} \\
2^{1}\end{array}$ & $\begin{array}{l}2^{4} \\
2^{4}\end{array}$ & $\begin{array}{l}2^{2} \\
2^{3}\end{array}$ & $\begin{array}{l}2^{4} \\
2^{3}\end{array}$ & $\begin{array}{l}2^{4} \\
2^{3}\end{array}$ & $\begin{array}{l}2^{4} \\
2^{3}\end{array}$ & $\begin{array}{l}2^{3} \\
2^{2}\end{array}$ \\
\hline $\begin{array}{l}\text { Prymnesiophyceae } \\
\text { Hymenomonas } \mathrm{sp} \\
\text { Pavlova salina }\end{array}$ & $\begin{array}{l}2^{3} \\
2^{3}\end{array}$ & $\begin{array}{l}2^{5} \\
2^{9}\end{array}$ & $\begin{array}{l}2^{13} \\
2^{12}\end{array}$ & $\begin{array}{l}2^{6} \\
2^{5}\end{array}$ & $\begin{array}{l}0 \\
2^{12}\end{array}$ & $\begin{array}{l}2^{6} \\
2^{12}\end{array}$ & $\begin{array}{l}2^{14} \\
2^{12}\end{array}$ & $\begin{array}{l}2^{7} \\
2^{10}\end{array}$ \\
\hline $\begin{array}{l}\text { Rhodophyceae } \\
\text { Porphyridium sp }\end{array}$ & $2^{5}$ & $2^{4}$ & 0 & $2^{5}$ & $2^{12}$ & $2^{7}$ & $2^{7}$ & $2^{8}$ \\
\hline
\end{tabular}

\section{Agglutination of hemophilia blood}

With the blood of hemophilia patients, all of the algae assayed agglutinated APTT type erythrocytes, while six of them reacted positively with PT type erythrocytes (Table 2). $P$. salina demonstrated the strongest activity ( $2^{20}$ titers) against PT erythrocytes, while Synechococcus sp was highly active towards both PT and APTT type erythrocytes.

\section{Agglutination of animal erythrocytes}

Differential preferences for animal erythrocytes were also distinct in unicellular algae. Nearly all of the algae assayed reacted strongly with native erythrocytes from monkey, but not from sheep erythrocytes (Table 3 ). Monkey erythrocytes are more susceptible to algal lectins than sheep erythrocytes in agglutination.

Table 2 Hemagglutinating activities of marine unicellular algae against native and trypsin-treated human coagulation disorder erythrocytes; the activity is expressed as titer

\begin{tabular}{|c|c|c|c|c|}
\hline \multirow[t]{2}{*}{ Algal species } & \multicolumn{2}{|c|}{ Native } & \multicolumn{2}{|c|}{ Trypsin } \\
\hline & PT & APTT & PT & APTT \\
\hline $\begin{array}{l}\text { Cynophyceae } \\
\text { Synechococcus sp }\end{array}$ & $2^{12}$ & $2^{12}$ & $2^{12}$ & $2^{14}$ \\
\hline $\begin{array}{l}\text { Chlorophyceae } \\
\text { Ankistrodesmus sp } \\
\text { Chlorella ellipoidea }\end{array}$ & $\begin{array}{l}0 \\
0\end{array}$ & $\begin{array}{l}2^{4} \\
2^{12}\end{array}$ & $\begin{array}{l}2^{1} \\
2^{1}\end{array}$ & $\begin{array}{l}2^{5} \\
2^{13}\end{array}$ \\
\hline $\begin{array}{l}\text { Dinophyceae } \\
\text { Gyrodinium instriatum } \\
\text { Prorocentrum minimum }\end{array}$ & $\begin{array}{l}2^{1} \\
2^{1}\end{array}$ & $\begin{array}{l}2^{1} \\
2^{1}\end{array}$ & $\begin{array}{l}2^{3} \\
2^{1}\end{array}$ & $\begin{array}{l}2^{3} \\
2^{1}\end{array}$ \\
\hline $\begin{array}{l}\text { Prymnesiophyceae } \\
\text { Hymenomonas sp } \\
\text { Pavlova salina }\end{array}$ & $\begin{array}{l}2^{12} \\
2^{20}\end{array}$ & $\begin{array}{l}2^{5} \\
2^{1}\end{array}$ & $\begin{array}{l}2^{1} \\
2^{14}\end{array}$ & $\begin{array}{l}2^{5} \\
2^{4}\end{array}$ \\
\hline $\begin{array}{l}\text { Rhodophyceae } \\
\text { Porphyridium sp }\end{array}$ & $2^{1}$ & $2^{1}$ & $2^{2}$ & $2^{3}$ \\
\hline
\end{tabular}


Table 3 Hemagglutinating activities of marine unicellular algae against animal erythrocytes; $\mathrm{N}$ : native, T: trypsin-treated, P: pronase-treated and the activity is expressed as titer

\begin{tabular}{llllllll}
\hline Algal species & \multicolumn{3}{c}{ Sheep } & & \multicolumn{3}{c}{ Monkey } \\
\cline { 2 - 3 } \cline { 5 - 7 } & $\mathrm{N}$ & $\mathrm{T}$ & $\mathrm{P}$ & $\mathrm{N}$ & $\mathrm{T}$ & $\mathrm{P}$ \\
\hline
\end{tabular}

\begin{tabular}{|c|c|c|c|c|c|c|}
\hline $\begin{array}{l}\text { Cynophyceae } \\
\text { Synechococcus sp }\end{array}$ & 0 & $2^{6}$ & $2^{6}$ & $2^{10}$ & $2^{18}$ & $2^{17}$ \\
\hline $\begin{array}{l}\text { Chlorophyceae } \\
\text { Ankistrodesmus sp } \\
\text { Chlorella ellipoidea }\end{array}$ & $\begin{array}{l}0 \\
0\end{array}$ & $\begin{array}{l}2^{11} \\
2^{6}\end{array}$ & $\begin{array}{l}2^{10} \\
2^{7}\end{array}$ & $\begin{array}{l}2^{11} \\
2^{11}\end{array}$ & $\begin{array}{l}2^{17} \\
2^{19}\end{array}$ & $\begin{array}{l}2^{18} \\
2^{18}\end{array}$ \\
\hline $\begin{array}{l}\text { Dinophyceae } \\
\text { Gyrodinium instriatum } \\
\text { Prorocentrum minimum }\end{array}$ & $\begin{array}{l}0 \\
0\end{array}$ & $\begin{array}{l}0 \\
0\end{array}$ & $\begin{array}{l}2^{3} \\
2^{3}\end{array}$ & $\begin{array}{l}0 \\
0\end{array}$ & $\begin{array}{l}2^{1} \\
0\end{array}$ & $\begin{array}{l}2^{5} \\
2^{8}\end{array}$ \\
\hline $\begin{array}{l}\text { Prymnesiophyceae } \\
\text { Hymenomonas sp } \\
\text { Pavlova salina }\end{array}$ & $\begin{array}{l}0 \\
0\end{array}$ & $\begin{array}{l}0 \\
0\end{array}$ & $\begin{array}{l}2^{11} \\
2^{2}\end{array}$ & $\begin{array}{l}2^{4} \\
2^{8}\end{array}$ & $\begin{array}{l}2^{13} \\
2^{17}\end{array}$ & $\begin{array}{l}2^{17} \\
2^{14}\end{array}$ \\
\hline $\begin{array}{l}\text { Rhodophyceae } \\
\text { Porphyridium sp }\end{array}$ & $2^{2}$ & $2^{3}$ & $2^{10}$ & $2^{7}$ & $2^{13}$ & $2^{14}$ \\
\hline
\end{tabular}

\section{Agglutination with enzyme-treated erythrocytes}

Pretreatment of erythrocytes with trypsin or pronase caused an increase of hemagglutinating activity in most of the assays, particularly in P. salina and Porphyridium sp for A and PT erythrocytes (Table 1, Figure 1). Meanwhile more species gave positive hemagglutination reactions after treatment with pronase than with trypsin. Each enzyme also inhibited markedly algal hemagglutination, eg Ankistrodesmus sp for $\mathrm{O}$ erythrocytes and Hymenomonas sp and $P$. salina for PT erythrocytes. The enzyme-induced activity peaks after treatment for $2 \mathrm{~h}$ or more (Figure 1 ). With animal erythrocytes, trypsin and pronase also improved detection, but the latter was superior to the former (Table 3).

\section{Hemagglutination of the combined algal extracts}

Agglutinating activities of the combined extracts varied with the species used. However, compared with individual species, the combined agglutinating activities were strongly inhibited in general (Table 4). The extremely active extracts of I. galbana and $P$. salina $\left(2^{20}\right.$ titer $)$ against native $\mathrm{PT}$ erythrocytes (Liao et al, unpublished) became inactive after combination. Similar results of abolished activity occurred in most of the combinations. In contrast, the combination of S. costatum with I. galbana resulted in a drastic increase of agglutination against sheep erythrocytes. Meanwhile, all of the combined extracts retained high activity against APTT erythrocytes.

\section{Inhibition of agglutination}

Both mono- and oligosaccharides inhibited algal extracts in agglutinating erythrocytes (Table 5). However, the inhibition patterns of sugars varied with the algae tested. It

Table 4 Agglutination of the combined extracts of two marine algae against native erythrocytes; the activity is expressed as titer. The numbers in parentheses indicate the individual activities of two corresponding species from Liao et al (unpublished data)

\begin{tabular}{lllll}
\hline Pairs of algal species & \multicolumn{4}{c}{ Erythrocyte } \\
\cline { 2 - 5 } & \multicolumn{1}{c}{ B } & \multicolumn{1}{c}{ PT } & APTT & Sheep \\
\hline Skeletonema costatum & $\left(0,2^{6}\right)$ & $\left(2^{14}, 2^{20}\right)$ & $\left(2^{12}, 2^{7}\right)$ & $(0,0)$ \\
Isochrysis galbana & $2^{8}$ & $2^{12}$ & $2^{6}$ & $2^{8}$ \\
S. costatum & $\left(0,2^{3}\right)$ & $\left(2^{14}, 0\right)$ & $\left(2^{12}, 2^{12}\right)$ & $(0,0)$ \\
Cyclotella sp & 0 & 0 & $2^{5}$ & 0 \\
S. costatum & $\left(0,2^{4}\right)$ & $\left(2^{14}, 2^{1}\right)$ & $\left(2^{12}, 2^{1}\right)$ & $\left(0,2^{2}\right)$ \\
Porphyridium sp & 0 & 0 & $2^{5}$ & $2^{2}$ \\
I. galbana & $\left(2^{6}, 2^{9}\right)$ & $\left(2^{20}, 2^{20}\right)$ & $\left(2^{7}, 2^{1}\right)$ & $(0,0)$ \\
Pavlova salina & 0 & 0 & $2^{5}$ & 0 \\
\hline
\end{tabular}
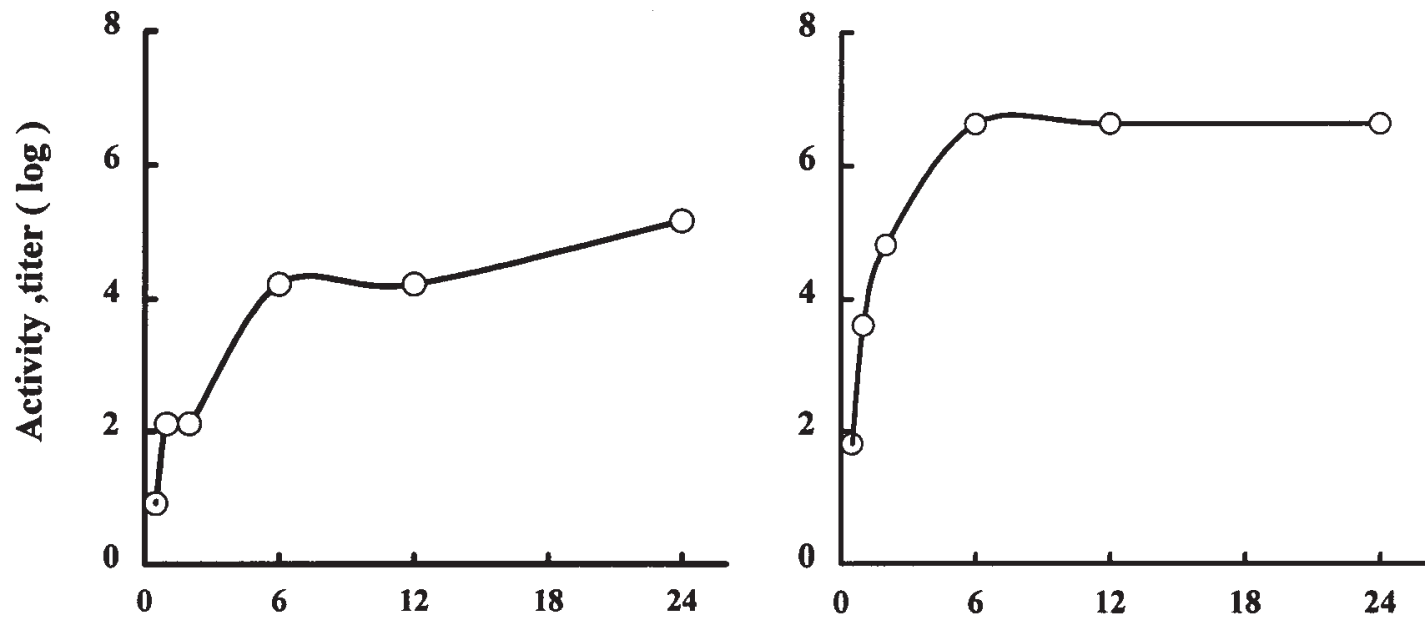

\section{Incubation time (h)}

Figure 1 Hemagglutination by algal extracts of pronase-treated erythrocytes at various time intervals of incubation (left: Hymenomonas sp with $\mathrm{O}$ erythrocytes, right: Porphyridium sp with PT erythrocytes). 
Table 5 Inhibition of algal agglutinating activity against native erythrocytes of human $\mathrm{O}$ group by sugars

\begin{tabular}{|c|c|c|c|c|c|c|c|c|c|}
\hline \multirow[t]{2}{*}{ Algal species } & \multicolumn{5}{|c|}{ Monosaccharides } & \multicolumn{4}{|c|}{ Oligosaccharides } \\
\hline & 1 & 2 & 3 & 4 & 5 & 6 & 7 & 8 & 9 \\
\hline Synechococcus sp & - & + & - & + & + & - & - & + & + \\
\hline Ankistrodesmus sp & + & + & + & + & + & + & + & - & - \\
\hline Gyrodinium instriatum & + & + & - & + & + & + & + & + & + \\
\hline Prorocentrum minimum & + & + & + & - & + & + & + & + & - \\
\hline Hymenomonas sp & - & - & + & - & - & + & + & - & - \\
\hline Pavlova salina & - & + & + & - & - & - & + & - & - \\
\hline Skeletonema costatum & + & + & + & + & + & + & + & + & - \\
\hline Cyclotella $\mathrm{sp}$ & + & + & + & - & + & + & + & + & - \\
\hline
\end{tabular}

1: D-glucose; 2: $\mathrm{D}(+)$-galactose; 3: $\mathrm{D}(+)$-mannose; 4: methyl- $\alpha$-D-glucoside; 5: methyl- $\alpha$-D-mannoside; 6: sucrose; 7: lactose; 8: L-lactose; 9: raffinose $+=$ inhibition, $-=$ noninhibition.

appeared that $\mathrm{D}(+)$-galactose and lactose inhibited all of the algae tested except Hymenomonas sp and Synechococcus sp, respectively. G. instriatum and $S$. costatum remained active with $\mathrm{D}(+)$-mannose and raffinose, respectively, but not with others.

\section{Discussion}

Like seaweeds, marine unicellular algae contain lectins that agglutinate human and animal erythrocytes to varying degrees. In light of their generally strong activities, marine unicellular algae are also a potent source of lectins for studies in biochemistry and medical applications.

Lectins of marine macroalgae have generally weak activity towards human erythrocytes, and are more specific for $\mathrm{A}$ and $\mathrm{B}$ than for $\mathrm{O}$ erythrocytes $[2,4,5,9,16]$. In this study, lectins in unicellular algae displayed comparatively high activities against human erythrocytes, particularly $\mathrm{O}$ and $\mathrm{AB}$ groups. Some of them have particularly interesting characteristics, eg extremely strong affinity for $\mathrm{O}$ erythrocytes by lectins from Synechococcus sp and Ankistrodesmus sp.

The generally strong activity against hemophilia erythrocytes in unicellular algae is most interesting since previous literature has rarely reported similar agglutination by marine macroalgae. These, together with our preliminary findings with chrysophyte cells (Liao et al, unpublished data) reveal that lectins which coagulate the anomalous blood, are widely distributed in marine unicellular algae.

Many authors used erythrocytes from sheep and other animals to assay hemagglutinins in seaweeds; they found a range of affinities with the algal species used $[1,5,9,12,14]$. In our study, most algae reacted strongly against monkey erythrocytes, but to a lesser extent or not at all with sheep erythrocytes.

Pretreatment of erythrocytes with enzymes, such as papain, neuraminidase, albumin, trypsin and pronase, can improve markedly the detection of lectins in seaweeds $[2,16,17]$. Such enzyme-dependent lectins are common in the algae assayed, however, the induced activity varies with the algal species. Meanwhile, treatment with pronase rather than trypsin could enhance all algal extracts to agglutinate both sheep and monkey erythrocytes. However, hemagglut- ination inhibition also occurred after enzyme treatment, particularly with human erythrocytes. Such enzyme inhibition has rarely been mentioned in the literature.

Lectins of seaweeds are generally characterized by glycoproteins, with or without binding to monosaccharides, and a requirement for divalent cations [17,18]. They specifically recognize and bind the carbohydrates in glycoproteins. Thus the sugar moiety of glycoproteins is the key in inhibiting algal hemagglutination. Many glycoproteins, glycopeptides and monosaccharides or simple sugars, eg Dglucose, D-mannose, D-galactose, D-fucose, $\mathrm{N}$ acetylgalactosamine and $N$-acetylglucosamine, inhibit specifically lectins of various seaweeds in hemagglutination $[5,11,17,18]$. Our study also demonstrated inhibition by monosaccharides and oligosaccharides of the agglutinating activity of marine microalgae. In view of the photosynthetic storage food in algal cells, members of Chrysophyceae, eg the diatoms S. costatum and Cyclotella sp and the flagellates $I$. galbana and $P$. salina, have abundant chrysolaminaran, a polysaccharide predominated by glucose, and considerable amounts of galactose, mannose, fructose and fucose $[6,7]$. Thus the strong hemagglutination inhibition in the combined extracts of this study probably arose largely if not entirely from the binding (primary and/or secondary) of one or more of the above or related simple sugars to the lectins within two algal species. We do not clearly know their interactions and binding processes. It appears that different algal combinations exhibited somewhat different patterns of agglutination against the erythrocytes assayed, implying a variety of cellular carbohydrates (both internal and external) between species and among taxonomic groups. Blunden et al [2] and Fabregas et al [9] revealed that hemagglutinins and their activities in marine algae are taxonomically significant. Others reported agglutination of blue-green algae by seaweed extract [11]. There remains much work to explore the biochemical characteristics of lectins in unicellular algae, particularly inter- or intraspecies reactions of algal cells with extracellular substances, with reproduction as well as symbiosis of bacteria or viruses on algal cells [3,8].

\section{Acknowledgements}

The authors gratefully acknowledge Shien-Chi Huang of the Union Clinical Laboratory (UCL), Taipei for providing human blood samples and Heui-Mei Su of the Tungkang Fisheries Institute, Taiwan for providing algal cultures.

\section{References}

1 Bird KT, TC Chiles, RE Longley, AF Kendrick and MD Kidema. 1993. Agglutinins from marine macroalgae of the southeastern United States. J Appl Phycol 5: 213-218.

2 Blunden G, DJ Rogers and WF Farnham. 1978. Haemagglutinins in British marine algae and their possible taxonomic value. In: Modern Approaches to the Taxonomy of Red and Brown Algae (Irvine DEG and JH Price, eds), pp 21-45, Academic Press, London.

3 Bolwell GP, JA Callow, ME Callow and LV Evans. 1977. Cross-fertilisation in fucoid seaweeds. Nature 268: 626-627.

4 Chiles TC and KT Bird. 1989. A comparative study of animal erythrocyte agglutinins from marine algae. Com Biochem Physiol 94B: 107-111.

5 Chiles TC and KT Bird. 1990. Gracilaria tikvahiae agglutinin. Partial 
purification and preliminary characterization of its carbohydrate specificity. Carbohydr Res 207: 319-326.

6 Craigie JS. 1974. Storage products. In: Algal Physiology and Biochemistry (Stewart WDP, ed), pp 206-235, University of California Press, Berkeley.

7 Darley WM. 1977. Biochemical composition. In: The Biology of Diatoms (Werner D, ed), pp 198-223, Blackwell Scientific Publications, Oxford.

8 Etzler ME. 1986. Distribution and function of plant lectins. In: The Lectins (Liener IE, N Sharon and IJ Goldstein, eds), pp 371-435, Academic Press, New York.

9 Fabregas J, J Liovo and A Munoz. 1985. Hemagglutinins in red seaweeds. Bot Mar 28: 517-520.

10 Guillard RRL and JH Ryther. 1962. Studies of marine planktonic diatoms. I. Cyclotella nana Hustedt and Detonula confervacea (Cleve) Gran. Can J Microbiol 8: 229-239.

11 Hori K, K Miyazawa and K Ito. 1986. Preliminary characterization of agglutinins from seven marine algal species. Bull Jap Soc Sci Fish 52: 323-331.

12 Hori K, H Matsuda, K Miyazawa and K Ito. 1987. Mitogenic aggluti- nin from the red alga Carpopeltis flabellata. Phytochemistry 26: 1335-1338.

13 Hori K, Y Shimada, C Oiwa, K Miyazawa and K Ito. 1993. Occurrence of a novel group of hemagglutinins extractable by pronase treatment in marine algae. J Appl Phycol 5: 219-223.

14 Kawakubo A, H Makino, J-I Ohnishi, H Hirohara and K Hori. 1997. The marine red alga Eucheuma serra J. Agardh, a high yielding source of two isolectins. J Appl Phycol 9: 331-338.

15 Lima HC, FH Costa, AH Sampaio, SA Neves, MB Benevides, DIA Teixeira, DJ Rogers and ALP Freitas. 1998. Induction and inhibition of human lymphocyte transformation by the lectin from the red marine alga Amansia multifida. J Appl Phycol 10: 153-162.

16 Rogers DJ, G Blunden, JA Topliss and MD Guiry. 1980. A survey of some marine organisms for hemagglutinins. Bot Mar 23: 569-577.

17 Rogers DJ and BC Fish. 1991. Marine algal lectins. In: Lectin Reviews (Kilpatrick DC, Van E Driessche and TC Bog-Hansen, eds), Vol 1, pp 129-142, Sigma Chemical Company, St Louis.

18 Rogers DJ and K Hori. 1993. Marine algal lectins: new developments. Hydrobiologia 260/261: 589-593. 